\title{
Pengaruh Brand Awareness Dan Brand Loyalty Terhadap Customer Purchase Decision Dengan Perceived Quality Sebagai Variabel Mediasi
}

\author{
Umi Nadhiroh $^{1}$, Rini Astuti ${ }^{2}$ \\ ${ }^{1}$ Prodi Manajemen Fakultas Ekonomi Universitas Islam Kadiri Kediri \\ ${ }^{2}$ Prodi Manajemen Fakultas Ekonomi Universitas Islam Kadiri Kediri \\ ${ }^{1}$ Email: uminadhiroh@uniska-kediri.ac.id \\ 2Email: riniastuti@uniska-kediri.ac.id
}

Received: 13 August 2021; Revised: 02 October 2021; Accepted: 14 December 2021

DOI: http://dx.doi.org/10.37905/aksara.8.1.401-412.2022

\begin{abstract}
Abstrak
Penelitian ini bertujuan untuk mengetahui apakah kesadaran merek dan loyalitas merek mempengaruhi keputusan pembelian pelanggan dengan persepsi kualitas sebagai variabel mediasi untuk penelitian di Joglo Suminar Batik Kediri. Jenis data yang digunakan dalam penelitian ini adalah data primer, metode pengumpulan data melalui wawancara dan kuesioner. Populasi dalam penelitian ini adalah seluruh konsumen batik suminar dengan sampel sebanyak 90 responden. Teknik pengambilan sampel yang digunakan dalam penelitian ini adalah teknik explanatory research. Analisis data menggunakan Analisis Jalur, Uji R2, dan Uji t. Hasil penelitian mengungkapkan bahwa Brand Awareness, Brand Loyalty, Perceived Quality berpengaruh terhadap keputusan pembelian pelanggan. Hal ini diketahui dari nilai signifikansi lebih besar dari tingkat signifikansi. Secara simultan atau simultan variabel independen Brand Awareness, Brand Loyalty dan variabel dependen keputusan pembelian pelanggan dan persepsi kualitas sebagai variabel mediasi mempengaruhi variabel dependen yaitu keputusan pembelian pelanggan, yang dibuktikan dengan nilai signifikansi yang lebih besar dari tingkat signifikansi. Dengan nilai thitung = 3,436, terdapat nilai sig > 0,05, maka variabel Perceived Quality memperkuat hubungan antara Kesadaran Merek dengan Keputusan Pembelian Pelanggan. Sedangkan dengan nilai thitung = 3,358 terdapat nilai sig < 0,05 maka variabel Perceived Quality memperkuat hubungan antara Loyalitas Merek dengan Keputusan Pembelian Pelanggan.
\end{abstract}

Kata Kunci: Kesadaran Merek, Loyalitas Merek, Keputusan Pembelian Pelanggan, Perceived Quality

\section{PENDAHULUAN}

Dimasa sekarang ini kain batik bukanlah suatu produk jadul atau kuno, tetapi kain batik merupakan warisan budaya Indonesia yang sangat istimewa di setiap pemakainya. Semakin berkembangnya motif-motif batik, maka produsen harus banyak berinovasi untuk membuat motif kain batik yang bisa menarik konsumen. Dengan inovasi motif batik terbaru, maka konsumen mempunyai rasa percaya diri yang lebih dengan memakai kain batik tersebut. Inovasi dan kreativitas anak bangsa akan batik tidak akan ada habisnya dan terus berkembang sesuai permintaan. Batik merupakan ciri khas daerah atau wilayah bahkan bisa mencirikan suatu negara. (Kusumodewi \& Sudarwanto, 2018). Dimasa sekarang ini bisnis batik mengalami perkembangan yang cukup signifikan. Hal ini bisa dilihat semakin menjamurnya UKM batik di berbagai wilayah di Indonesia. Dalam hal ini, pemerintah harus terus mengembangkan dan memperhatikan kemajuan UKM tersebut dengan memberikan pemodalan dan fasilitas pada usaha mereka. Setiap daerah / wilayah mempunyai potensi atau kekhasan (ciri khas) yang terdapat di daerah tersebut dan potensi tersebut bisa diangkat ke tingkat nasional atau bahkan internasional. Dengan ciri khas tersebut akan menonjolkan kearifan lokal masing masing daerah / wilayah yang diangkat ke tingkat yang lebih luas lagi. Batik merupakan kerajinan yang mempunyai nilai seni tinggi dan telah menjadi warisan dari 
budaya Indonesia, khususnya di pulau Jawa. Penetapan batik sebagai warisan budaya asli Indonesia oleh UNESCO membuat masyarakat Indonesia mulai tertarik kembali untuk menggunakan pakaian batik. Hal ini, membuat persaingan semakin ketat dikalangan pengrajin batik untuk menciptakan model, desain, serta motif batik yang dapat membuat konsumen puas. Perilaku pembelian seorang konsumen dapat dikatakan sesuatu yang unik, karena prefensi dan sikap terhadap obyek setiap orang berbeda. Selain itu konsumen juga berasal dari berbagai segmen, sehingga apa yang diinginkan dan dibutuhkan berbeda-beda.(Kusuma, 2018)

Faktor pertama yang dapat mempengaruhi customer purchase decision adalah brand awareness. Pada dasarnya konsumen akan membeli sebuah produk yang telah dikenali dan sudah berada dalam benak konsumen. Hal ini dapat meningkatkan rasa percaya diri konsumen untuk pengambilan keputusan dalam pembelian. Semantara itu, brand awarness dapat meningkatkan daya beli konsumen dan pertumbuhan keuntungan perusahaan. Penelitian mengenai brand awareness memiliki pengaruh terhadap customer purchase decision dilakukan oleh Khasanah (2013), Fatimah (2014), Ratung et al. (2014), dan Anwar et al. (2018). Namun, hasil penelitian Pradipta et al. (2016) menemukan bahwa brand awareness tidak berpengaruh terhadap customer purchase decision.(Chandra \& Keni, 2019)

Brand association juga menjadi salah satu faktor yang dapat mempengaruhi customer purchase decision. Menurut Sudomo (2013), brand association merupakan segala sesuatu yang berkaitan dengan ingatan terhadap suatu merek. Jadi, brand association dapat diartikan sebagai segala kesan yang muncul dibenak seseorang, yang berhubungan dengan ingatannya mengenai sebuah merek. Ingatan berbagai informasi dan kesan mengenai suatu brand sangat berguna bagi konsumen dalam proses pengambilan keputusan pembelian yang dilakukan. Brand association positif dapat menghasilkan brand image yang sesuai dengan keinginan konsumen, sehingga akan berdampak dalam pengambilan keputusan pembelian terhadap merek (Khasanah, 2013). Hasil penelitian yang dilakukan Khasanah (2013), Pujianingrum (2017), serta Adam dan Akber(2016) nemenukan bahwa brand association berpengaruh terhadap customer purchase decision. Namun, hasil penelitian Prajapati dan Makwana (2017) yang menemukan bahwa brand association tidak berpengaruh terhadap customer purchase decision.(Saputro, 2015)

Perceived quality yang terdapat pada sebuah produk merupakan salah satu faktor penting bagi konsumen untuk melakukan pengambilan keputusan dalam pembelian. Menurut Dib dan Alhaddad (2014), perceived quality merupakan penilaian dari pelanggan mengenai keunggulan atau kelebihan produk dibandingkan merek alternatif, yang pada akhirnya dapat memberikan motivasi pelanggan untuk melakukan pembelian produk. Selain itu, dapat diketahui bahwa produk yang memiliki kualitas yang lebih baik dan terjamin dari pesaing, akan meningkatkan keputusan konsumen untuk membeli produk tersebut. Hasil penelitian Khasanah (2013), Ratung et al. (2014), dan Siali et al. (2016) menunjukkan bahwa perceived quality berpengaruh terhadap customer purchase decision. Namun, hasil penelitian Nazaruddin dan Fikri (2013) menemukan bahwa perceived quality tidak berpengaruh terhadap customer purchase decision.

Selain itu, faktor yang dapat mempengaruhi customer purchase decision adalah brand loyalty. Menurut Winatapradja (2013), brand loyalty merupakan sebuah ukuran mengenai kedekatan pelanggan terhadap sebuah merek. Umumnya konsumen yang 
loyal akan melanjutkan pembelian walaupun dihadapkan pada alternatif produk yang menawarkan produk lebih unggul. Brand loyalty ini juga dapat menunjukkan bahwa harapan konsumen terhadap sebuah produk dapat terpenuhi, maka sebagai akibatnya konsumen akan mengambil keputusan untuk membeli produk yang ditawarkan terusmenerus. Hasil penelitian Fatimah (2014), Pujianingrum (2017), dan Siali et al. (2016) yang menemukan bahwa brand loyalty berpengaruh terhadap customer purchase decision. Namun, hasil penelitian Rahmadhano (2014) menunjukkan bahwa brand loyalty tidak berpengaruh terhadap customer purchase decision.(Taufiq, 2014)

Dalam penelitian ini dapat di temukan fenomena di mana konsumen yang sadar akan keberadaan merek tersebut sudah mampu memberikan persepsi atas kualitas produk dari merek yang mereka gunakan sehingga loyal terhadap merek tersebut. Namun yang menjadi pertanyaan dari penelitian ini, apakah konsumen yang telah loyal terhadap merek yang memiliki berbagai variasi jenis produk akan tetap memiliki niat membeli produknya yang lain dalam merek yang sama.(Saputro, 2015).

\section{METODE PENELITIAN}

Pendekatan penelitian ini dilakukan dengan deskriptif kuantitatif dan sumber data yang digunakan dalam penelitian ini adalah data primer yaitu data yang diperoleh langsung dari sumber dimana penelitian dilakukan secara langsung. Dalam penelitian ini data primer diperoleh melalui jawaban kuesioner yang dibagikan kepada responden. Populasi dalam penelitian ini adalah seluruh konsumen batik suminar dengan sampel yang digunakan sebanyak 90 responden. Teknik pengambilan sampel yang digunakan dalam penelitian ini adalah teknik explanatory research yaitu penelitian yang bertujuan menjelaskan hubungan kausal antara variabel-variabel melalui pengujian hipotesis.

Data dianalisis dengan menggunakan Analisis Jalur (Path Analysis), Uji R ${ }^{2}$, dan Uji t. Teknik ini digunakan untuk mengetahui pengaruh secara langsung dan tidak langsung antar variabel bebas dan variabel terikat dan menguji peran suatu variabel moderasi. Dalam penelitian ini digunakan untuk mengetahui peran Perceived Quality dalam memediasi Brand Awareness, Brand Loyalty terhadap Customer Purchase Decision. Variabel penelitian diukur menggunakan Skala Likert 1 sampai dengan 5, dioperasional.

Kesadaran merek merupakan suatu penerimaan dari konsumen terhadap suatu merek dalam benak mereka, dimana hal itu ditunjukkan dari kemampuan konsumen dalam mengingat dan mengenali ciri khas sebuah merek, dan mengaitkannya kedalam kategori tertentu. Dengan meningkatkan brand awareness akan berimbas pada perluasan target market. Winatapradja (2013:959), menyatakan bahwa brand awareness merupakan "kesanggupan seorang pembeli untuk mengenali atau mengingat kembali bahwa suatu merek merupakan bagian dari katagori produk tertentu". Selain itu, Anwar et al. (2018:215) berpendapat bahwa "brand awareness is the way of consumer to notice the brand and try to recall the brand by memorizing the brand from the certained product itself". Semantara itu, Ambolau et al. (2015:4), menyatakan "brand awareness is an ability of consumers to identify the brand under different conditions, can be done with the brand recognition and recall to a particular brand." Dari definisi yang telah diuraikan dapat disimpulkan bahwa brand awareness merupakan kempauan konsumen untuk mengenali dan mengingat kembali sebuah merek dengan cukup rinci untuk melakukan pembelian.(Chandra \& Keni, 2019) 
Semakin tinggi tingkat kesadaran tentang merek, berarti produk tersebut berada dalam benak konsumen sebelum merek lain (Durianto dkk., 2010). Selanjutnya kesadaran merek bukan menjadi suatu daya ingat saja, namun merupakan suatu proses pembelajaran bagi konsumen terhadap suatu merek. Membangun kesadaran merek biasanya dilakukan dalam waktu yang lama karena penghafalan bisa berhasil dengan repetisi dan penguatan. Dalam kenyataannya, merek-merek dengan tingkat pengingatan kembali yang tinggi merupakan merek-merek yang berusia lama.(Taufiq, 2014).

Brand loyalty adalah suatu tolak ukur kesetiaan konsumen pada suatu brand. Loyalitas pelanggan ini dapat mengetahui apa konsumen akan berpindah merek, terutama apabila produk dari merek tersebut mengalami perubahan harga, design maupun material. Jika loyalitas meningkat maka kemungkinan perpindahan produk atau merek dapat diminimalisasi. Konsumen yang setia biasanya akan tetap setia pada satu merek saja.

Menurut Sudomo (2013:37), "brand loyalty merupakan ukuran kesetiaan konsumen terhadap merek. Konsumen yang loyal umumnya akan setia pada merek tersebut dalam hal pembelian ulang walaupun dihadapkan pada berbagai alternatif pilihan merek lain". Sementara menurut Pulungan et al. (2016:32), mengungkapkan bahwa "brand loyalty is a measure of closeness or customer relationship with a brand. This illustrates the size of the possible absence of customers switching to other brands, especially if the brand changed both concerning priceor other attributes".(Kusumodewi \& Sudarwanto, 2018)

Menurut Fadhilah (2015:194), "loyalitas merek merupakan ukuran kesetiaan, kedekatan atau keterkaitan konsumen pada sebuah merek. Ukuran ini mampu memberikan gambaran tentang mungkin tidaknya konsumen beralih ke merek produk yang lain". Dari definisi yang telah diuraikan dapat disimpulkan bahwa brand loyalty merupakan ukuran kesetiaan pelanggan pada sebuah merek. Konsumen yang loyal pada umumnya akan melanjutkan penggunaan merek tersebut walaupun dihadapkan dengan banyak alternatif merek produk yang lebih unggul.(Taufiq, 2014)

Brand loyalty merupakan suatu ukuran loyalitas konsumen terhadap suatu merek. Ukuran loyalitas konsumen ini dapat memberikan gambaran mungkin tidaknya konsumen beralih ke merek lain, terutama jika merek tersebut mengalami perubahan baik yang menyangkut harga maupun atribut lain.Bila loyalitas pelanggan terhadap suatu merek meningkat, kerentanan kelompok pelanggan tersebut dari ancaman dan serangan merek produk pesaing dapat dikurangi. Pelanggan yang loyal pada umumnya akan melanjutkan pembelian terhadap merek tersebut, walaupun dihadapkan pada banyak alternatif merek.(Fabbe-Costes et al., 2014).

Maindoka et al. (2014:985) mengungkapkan bahwa customer purchase decision atau dapat dikatakan buying decision ini merupakan "the stage in which consumers make the decision ortake an action whether to purchase a certain product or not". Ambolau et al. (2015:2) menyatakan bahwa "purchase decisions are actions taken by consumer to purchase a product. Therefore, the consumer purchase decision making is a process of selection of one of several alternatives to solve problem by real actions. After that, consumers can evaluate options and then can determine the decision to be taken". Selain itu, Pradipta et al. (2016:141), mengungkapkan "keputusan pembelian merupakan suatu keputusan final yang dimiliki seorang konsumen untuk membeli suatu barang atau jasa dengan berbagai pertimbangan-pertimbangan tertentu. Keputusan 
pembelian yang dilakukan oleh konsumen menggambarkan seberapa jauh pemasar dalam usaha memasarkan suatu produk ke konsumen". Dari definisi yang telah diuraikan dapat disimpulkan bahwa customer purchase decision merupakan tindakan yang diambil oleh konsumen untuk membeli sebuah poduk, dengan melakukan pertimbangan-pertimbangan tertentu.(Saputro, 2015).

Dib dan Alhaddad (2014:184), menyatakan jika "perceived quality is defined as the customer's judgment about a product's overall excellence or superiority in comparison to alternative's brand and overall superiority that ultimately motivates the customer to purchase the product". Selain itu, Jintu et al. (2013:4) berpendapat bahwa "persepsi kualitas menggambarkan respon pelanggan terhadap kualitas keunggulan yang ditawarkan merek. Respon ini adalah persepsi yang terbentuk dari pengalaman selama berinteraksi dengan merek melalui komunikasi yang dibangun oleh pemasar". Priansa (2017:260), mengatakan jika "perceived quality merupakan anggapan atau persepsi konsumen mengenai suatu produk yang dilihat melalui fisik suatu barang ataupun psikis konsumen sendiri". Dari definisi yang telah diuraikan dapat disimpulkan bahwa perceived quality merupakan respon konsumen terhadap keseluruhan kualitas produk atau jasa yang diberikan sebuah merek.(Kusumodewi \& Sudarwanto, 2018)

\section{HASIL PENELITIAN DAN PEMBAHASAN}

Analisis Regresi Linier Pengaruh Brand Awareness dan Brand Loyalty Terhadap Customer Purchase Decision

Model regresi pertama dalam penelitian ini bertujuan untuk menganalisis seberapa pengaruh variabel Brand Awareness dan Brand Loyalty Terhadap Customer Purchase Decision. Berikut adalah hasil analisis linier berganda dengan menggunakan SPSS versi 25:

Tabel. 1 Hasil Uji Linier Barganda Pengaruh Brand Awareness Terhadap Customer Purchase Decision

Coefficients $^{\mathbf{a}}$

\begin{tabular}{|ll|l|l|l|l|l|}
\hline \multirow{2}{*}{ Model } & \multicolumn{2}{|l|}{$\begin{array}{l}\text { Unstandardized } \\
\text { Coefficients }\end{array}$} & \multicolumn{2}{|l|}{$\begin{array}{l}\text { Standardized } \\
\text { Coefficients }\end{array}$} & & \\
\cline { 2 - 5 } & B & Std. Error & Beta & t & Sig. \\
\hline 1 & (Constant) & 4.432 & 1.142 & & 3.880 & .000 \\
& BRAND AWARENESS & .535 & .110 & .444 & 4.864 & .000 \\
BRAND LOYALTY & .707 & .138 & .467 & 5.111 & .000 \\
\hline
\end{tabular}

a. Dependent Variable: CUSTOMER PURCHASE DECISION

Sumber: Data diolah, 2021

Dari hasil analisis dengan program SPSS versi 25 tersebut, maka diketahui brand awareness dan brand loyalty terhadap customer purchase decision berpengaruh langsung, dalam analisis jalur ini ditunjukkan pada gambar berikut ini: 


\section{Pengaruh Langsung}

Pengaruh langsung dalam analisis jalur ini ditunjukkan pada gambar berikut ini:

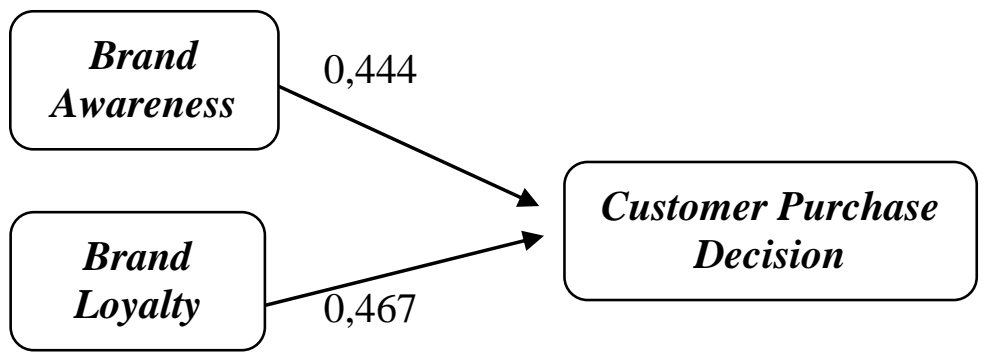

Gambar 1. Parameter Pengaruh Langsung Brand Awareness dan Brand Loyalty terhadap Customer Purchase Decision

Dari tabel 1 dan gambar 1 diatas disimpulkan bahwa pada variabel brand awareness ditemukan nilai signifikan sebesar 0,000 < 0,05, artinya Ho ditolak dan Ha diterima. Maka variabel brand awareness berpengaruh secara langsung terhadap customer purchase decision. Pada variabel brand loyalty ditemukan nilai signifikan sebesar 0,000 < 0,05, artinya Ho ditolak dan Ha diterima. Maka, variabel brand loyalty berpengaruh secara langsung terhadap customer purchase decision. Pada variabel brand awareness ditemukan nilai koefisien beta sebesar 0,444. Artinya, terdapat pengaruh langsung antara brand awareness terhadap customer purchase decision sebesar 0,444. Pada variabel brand loyalty ditemukan nilai koefisien beta sebesar 0,467. Artinya, terdapat pengaruh langsung antara brand loyalty terhadap customer purchase decision sebesar 0,467. Jumlah pengaruh langsung antara brand awareness dan brand loyalty terhadap customer purchase decision adalah 0,444 x 0,467 =0,207348.

\section{Analisis Regresi Linier Pengaruh Brand Awareness dan Brand Loyalty Terhadap Customer Purchase Decision Dengan Perceived Quality Sebagai Variabel Mediasi}

Model regresi kedua dalam penelitian ini bertujuan untuk menganalisis seberapa pengaruh variabel brand awareness dan brand loyalty terhadap customer purchase decision dengan perceived quality sebagai variabel mediasi. Berikut adalah hasil analisis linier sederahan dengan menggunakan SPSS versi 25:

Tabel. 2 Hasil Uji Linier Barganda Pengaruh Brand Awareness dan Brand Loyalty Terhadap Customer Purchase Decision Dengan Perceived Quality Sebagai Variabel Mediasi

\section{Coefficients $^{\mathrm{a}}$}

\begin{tabular}{|c|c|c|c|c|c|c|}
\hline \multirow{2}{*}{\multicolumn{2}{|c|}{ Model }} & \multicolumn{2}{|c|}{$\begin{array}{l}\text { Unstandardized } \\
\text { Coefficients }\end{array}$} & \multirow{2}{*}{\begin{tabular}{|l} 
Standardized \\
Coefficients
\end{tabular}} & \multirow[b]{2}{*}{$\mathrm{t}$} & \multirow[b]{2}{*}{ Sig. } \\
\hline & & B & Std. Error & & & \\
\hline 1 & (Constant) & 2.301 & .908 & & 2.534 & .013 \\
\hline & Brand Awareness & .304 & .088 & .252 & 3.436 & .001 \\
\hline & Brand Loyalty & .379 & .113 & .250 & 3.358 & .001 \\
\hline & Perceived Quality & .663 & .083 & .508 & 8.031 & .000 \\
\hline
\end{tabular}




\section{Coefficients $^{\mathrm{a}}$}

\begin{tabular}{|c|c|c|c|c|c|c|}
\hline \multirow{2}{*}{\multicolumn{2}{|c|}{ Model }} & \multicolumn{2}{|c|}{$\begin{array}{l}\text { Unstandardized } \\
\text { Coefficients }\end{array}$} & \multirow{2}{*}{\begin{tabular}{|l} 
Standardized \\
Coefficients
\end{tabular}} & \multirow[b]{2}{*}{$\mathrm{t}$} & \multirow[b]{2}{*}{ Sig. } \\
\hline & & B & Std. Error & & & \\
\hline \multirow[t]{4}{*}{1} & (Constant) & 2.301 & .908 & & 2.534 & .013 \\
\hline & Brand Awareness & .304 & .088 & .252 & 3.436 & .001 \\
\hline & Brand Loyalty & .379 & .113 & .250 & 3.358 & .001 \\
\hline & Perceived Quality & .663 & .083 & .508 & 8.031 & .000 \\
\hline
\end{tabular}

a. Dependent Variable: Customer Purchase Decision

Sumber: Data diolah, 2021

Dari hasil analisis dengan program SPSS versi 25 tersebut, maka diketahui brand awareness dan brand loyalty terhadap customer purchase decision dengan perceived quality sebagai variabel mediasi berpengaruh tidak langsung.

\section{Pengaruh Tidak Langsung}

Pengaruh tidak langsung dalam analisis jalur ini ditunjukkan pada gambar berikut ini:

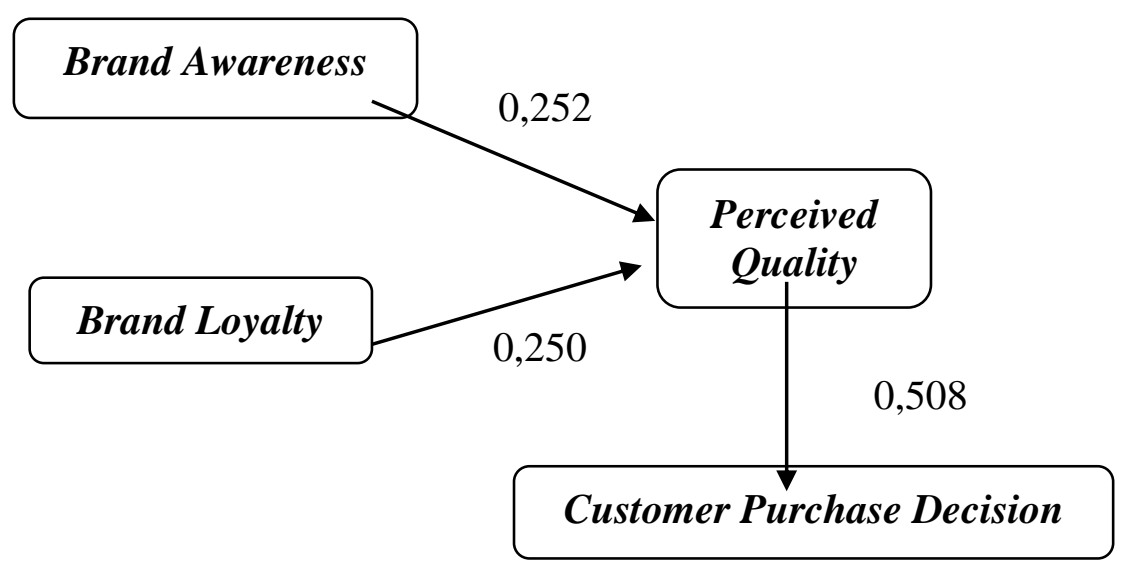

\section{Gambar 2.Parameter Pengaruh Tidak Langsung Brand Awareness dan Brand Loyalty terhadap Customer Purchase Decision}

Berdasarkan tabel 2 dan gambar 2 diatas disimpulkan bahwa pada variabel brand awareness ditemukan nilai signifikan sebesar 0,001 < 0,05, artinya Ho ditolak dan Ha diterima. Maka, variabel brand awareness berpengaruh secara tidak langsung terhadap customer purchase decision. Pada variabel brand loyalty ditemukan nilai signifikan sebesar 0,001 < 0,05, artinya Ho ditolak dan Ha diterima. Maka, variabel brand loyalty berpengaruh secara tidak langsung terhadap customer purchase decision. Pada variabel perceived loyalty nilai signifikan sebesar $0,000<0,05$, artinya Ho ditolak dan Ha diterima. Maka, variabel perceived loyalty berpengaruh secara tidak langsung terhadap customer purchase decision. Pada variabel brand awareness ditemukan nilai koefisien beta sebesar 0,252. Artinya, terdapat pengaruh tidak langsung antara brand awareness terhadap customer purchase decision sebesar 0,252. Pada variabel brand loyalty ditemukan nilai koefisien beta sebesar 0,250. Artinya, terdapat pengaruh tidak langsung 
antara brand awareness terhadap customer purchase decision sebesar 0,250. Pada variabel perceived loyalty ditemukan nilai koefisien beta sebesar 0,508. Artinya, terdapat pengaruh tidak langsung antara perceived loyalty terhadap customer purchase decision sebesar 0,508. Jumlah pengaruh tidak langsung antara brand awareness, brand loyalty dan perceived loyalty terhadap customer purchase decision adalah $0,252 \times 0,250$ x $0,508=0,032004$.

Berdasarkan keterangan dari pengaruh langsung dan tidak langsung antara variabel brand awareness dan brand loyalty terhadap customer purchase decision dengan variabel perceived loyalty sebagai mediasi diperoleh nilai total pengaruhnya sebesar 0,239352 dari penjumlah nilai langsung dan tidak langsung yaitu: 0,207348 + 0,032004 .

\section{Koefisien Determinasi Pengaruh Brand Awareness dan Brand Loyalty Terhadap Customer Purchase Decision}

Koefisien determinasi model regresi pertama digunakan untuk mengetahui seberapa jauh atau seberapa besar variabel brand awareness dan brand loyalty mampu menjelaskan terhadap variable customer purchase decision, dimana ditunjukkan dengan nilai $R$ Square. Untuk mengetahui seberapa besar customer purchase decision mampu dijelaskan oleh variabel brand awareness dan brand loyalty, maka berikut hasil pengujian yang dibantu dengan program SPSS 16 adalah:

Tabel. 3 Hasil Uji Koefisien Determinasi Pengaruh Brand Awareness dan Brand Loyalty Terhadap Customer Purchase Decision

Model Summary

\begin{tabular}{|l|l|l|l|l|}
\hline Model & $\mathrm{R}$ & R Square & Adjusted R Square & Std. Error of the Estimate \\
\hline 1 & $.866^{\mathrm{a}}$ & .751 & .745 & 1.92570 \\
\hline
\end{tabular}

a. Predictors: (Constant), Brand Loyalty, Brand Awareness

Sumber: Data diolah, 2021

Dari tabel diatas, angka koefisien determinasi ( $R$ Square) sebesar 0,751. Hal ini berarti bahwa variabel brand awareness dan brand loyalty mempunyai peranan $75,1 \%$ secara bersama-sama untuk dapat menjelaskan atau menerangkan variabel Kinerja Karyawan. Sedangkan sisanya sebesar 24,9\% (100\% - 75,1\%) dijelaskan oleh variabel lain yang mempengaruhi customer purchase decision.

\section{Koefisien Determinasi Pengaruh Brand Awareness dan Brand Loyalty Terhadap Customer Purchase Decision Dengan Perceived Quality Sebagai Variabel Mediasi}

Koefisien determinasi model regresi kedua digunakan untuk mengetahui seberapa jauh atau seberapa besar variabel brand awareness, brand loyalty, dan perceived quality serta interaski antara brand awareness, brand loyalty, dan perceived quality mampu menjelaskan terhadap variabel customer purchase decision, dimana ditunjukkan dengan nilai $R$ Square. Untuk mengetahui seberapa besar customer purchase decision mampu dijelaskan oleh ketiga variabel yaitu brand awareness, brand loyalty, dan perceived quality, serta interaski antara brand awareness, brand loyalty, dan perceived quality maka berikut hasil pengujian yang dibantu dengan program SPSS 25 adalah: 
AKSARA: Jurnal Ilmu Pendidikan Nonformal

P-ISSN 2407-8018 E-ISSN 2721-7310 DOI prefix 10.37905

Volume 08, (1), January 2022

http://ejurnal.pps.ung.ac.id/index.php/Aksara

Tabel. 4 Hasil Uji Koefisien Determinasi Pengaruh Brand Awareness dan Brand Loyalty Terhadap Customer Purchase Decision Dengan Perceived Quality Sebagai Variabel Mediasi

Model Summary

\begin{tabular}{|l|l|l|l|l|}
\hline Model & $\mathrm{R}$ & R Square & Adjusted R Square & Std. Error of the Estimate \\
\hline 1 & $.926^{\mathrm{a}}$ & .858 & .853 & 1.46414 \\
\hline
\end{tabular}

a. Predictors: (Constant), Perceived Quality, Brand Awareness, Brand Loyalty

Sumber: Data diolah, 2021

Dari tabel diatas, angka koefisien determinasi ( $R$ Square) sebesar 0,858 . Hal ini berarti bahwa variabel brand awareness, brand loyalty, dan perceived quality serta interaski antara brand awareness, brand loyalty, dan perceived quality mempunyai peranan $85,8 \%$ secara bersama-sama untuk dapat menjelaskan atau menerangkan variabel customer purchase decision. Sedangkan sisanya sebesar 14,2\% (100\% - 85,8\%) dijelaskan oleh variabel lain yang mempengaruhi customer purchase decision.

\section{Pengujian Hipotesis}

Uji hipotesis 1 sampai dengan 4 diuji dengan uji parameter individual (uji statistik t) yang bertujuan untuk mengetahui besarnya pengaruh masing-masing variabel independen secara parsial (individu) terhadap variabel dependen. Nilai dari uji t dilihat $p$-value (pada kolom sig) pada masing-masing variabel independen. Jika nilai $p$-value lebih kecil dari level of signifikan 0,05 . Hasil dari analisis adalah sebagai berikut:

\section{Pengujian Hipotesis Pengaruh Brand Awareness dan Brand Loyalty Terhadap Customer Purchase Decision}

Dari tabel 1, hasil perhitungan yang telah dilakukan diperoleh nilai $t_{\text {hitung }}$ untuk Brand Awareness adalah 4,864 dengan nilai signifikansi sebesar 0,000 sedangkan melalui level of significance (taraf signifikansi) sebesar 0,05 . Sehingga $t_{\text {hitung }}$ dan nilai probabilitas lebih kecil dari 0,05. Dengan hasil tersebut dapat disimpulkan bahwa pengujian tersebut menunjukkan pengaruh yang signifikan antara Brand Awareness terhadap Customer Purchase Decision. Hasil perhitungan yang telah dilakukan diperoleh nilai thitung untuk Brand Loyalty adalah 5,111 dengan nilai signifikansi sebesar 0,000, sedangkan melalui level of significance (taraf signifikansi) sebesar 0,05.

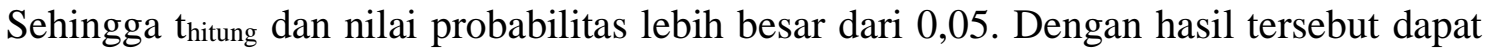
disimpulkan bahwa pengujian tersebut menunjukkan pengaruh yang tidak signifikan antara Brand Loyalty terhadap Customer Purchase Decision.

Pengujian Hipotesis Pengaruh Brand Awareness dan Brand Loyalty Terhadap Customer Purchase Decision Dengan Perceived Quality Sebagai Variabel Mediasi

Dari tabel 2, hasil perhitungan yang telah dilakukan, maka diperoleh $t_{\text {hitung }}$ untuk variabel interaksi Brand Awareness dengan Perceived Quality adalah sebesar 3,436 dengan hasil signifikansinya 0,001 sedangkan melalui level of significance (taraf signifikansi) sebesar 0,05. Sehingga $t_{\text {hitung }}$ dan nilai probabilitas lebih besar dari 0,05 . Dengan hasil tersebut dapat disimpulkan bahwa Brand Awareness berpengaruh terhadap Perceived Quality. 
Hasil perhitungan yang telah dilakukan, maka diperoleh $t_{\text {hitung }}$ untuk variabel interaksi Brand Loyalty dengan Perceived Quality adalah sebesar 3,358 dengan hasil signifikansinya 0,001 sedangkan melalui level of significance (taraf signifikansi) sebesar 0,05. Sehingga $t_{\text {hitung }}$ dan nilai probabilitas lebih kecil dari 0,05. Dengan hasil tersebut dapat disimpulkan bahwa Brand Loyalty berpengaruh terhadap Perceived Quality.

Dari hasil perhitungan yang telah dilakukan, makan diperoleh $t_{\text {hitung }}$ untuk variabel interaksi Perceived Quality dengan Customer Purchase Decision adalah sebesar 8,031 dengan hasil signifikansinya 0,000 sedangkan melalui level of significance (taraf signifikansi) sebesar 0,05. Sehingga thitung dan nilai probabilitas lebih besar dari 0,05. Dengan hasil tersebut dapat disimpulkan bahwa Perceived Quality berpengaruh terhadap Customer Purchase Decision.

\section{KESIMPULAN}

Nilai variabel Brand Awareness yaitu 0,444 terdapat nilai sig < 0,05, maka Ho ditolak dan Ha diterima, sehingga Brand Awareness berpengaruh secara langsung terhadap Customer Purchase Decision pada konsumen Joglo Suminar Batik Kediri. Sedangkan, nilai dari variabel Brand Loyalty yaitu 0,467 terdapat nilai sig > 0,05, maka Ho ditolak dan Ha diterima, sehingga Brand Loyalty berpengaruh secara langsung terhadap Customer Purchase Decision pada konsumen Joglo Suminar Batik Kediri.

Nilai dari variabel Brand Awareness yaitu 0,252 terdapat nilai sig > 0,05, maka Ho ditolak dan Ha diterima, sehingga Brand Awareness berpengaruh secara tidak langsung terhadap Customer Purchase Decision pada konsumen Joglo Suminar Batik Kediri. Sedangkan, nilai dari variabel Brand Loyalty yaitu 0,250 terdapat nilai sig < 0,05, maka Ho ditolak dan Ha diterima, sehingga Brand Loyalty berpengaruh secara tidak langsung terhadap Customer Purchase Decision pada konsumen Joglo Suminar Batik Kediri.

Nilai dari variabel Customer Purchase Decision yaitu 0,508 dengan terdapat nilai sig > 0,05, maka Ho ditolak dan Ha diterima, sehingga Perceived Quality berpengaruh secara tidak langsung terhadap Customer Purchase Decision pada konsumen Joglo Suminar Batik Kediri.

Nilai $\mathrm{t}_{\text {hitung }}=3,436$ terdapat nilai sig $>0,05$, maka variabel Perceived Quality memperkuat hubungan Brand Awareness terhadap Customer Purchase Decision. Sedangkan dengan nilai $t_{\text {hitung }}=3,358$ terdapat nilai sig $<0,05$, maka variabel Perceived Quality memperkuat hubungan Brand Loyalty terhadap Customer Purchase Decision.

\section{SARAN}

Saran yang dapat diberikan adalah sebagai berikut: Penelitian ini menggunakan 2 variabel independen dan 1 variabel mediasi yang mempengaruhi Customer Purchase Decision pada konsumen Joglo Suminar Batik Kediri. Oleh karena itu, penulis mengharapkan partisipasi aktif peneliti berikutnya untuk meneliti faktor-faktor lain yang dapat mempengaruhi Customer Purchase Decision pada konsumen Joglo Suminar Batik Kediri, sehingga diperoleh hasil penelitian yang tingkat generalisasi lebih tinggi. 


\section{REFERENCES}

Chandra, C., \& Keni, K. (2019). Pengaruh Brand Awareness, Brand Association, Perceived Quality, Dan Brand Loyalty Terhadap Customer Purchase Decision. Jurnal Muara Ilmu Ekonomi Dan Bisnis, 3(1), 176. https://doi.org/10.24912/jmieb.v3i1.3506

Fabbe-Costes, N., Roussat, C., Taylor, M., \& Taylor, A. (2014). Sustainable supply chains: A framework for environmental scanning practices. International Journal of Operations and Production Management. https://doi.org/10.1108/IJOPM-102012-0446

Kusuma, N. B. A. P. dan I. P. M. (2018). Brand Awareness, Brand Loyalty, Perceived Quality, Brand Association Brand Preference dan Purchase Intention. Jurnal Manajemen Dan Bisnis, 15(2), 100-119.

Kusumodewi, G., \& Sudarwanto, T. (2018). Pengaruh Gaya Hidup, Kualitas Produk \& Harga Terhadap Keputusan Pembelian Kain Batik Mirota Surabaya. Program Studi Tata Niaga Universitas Surabaya, 1-9.

Saputro, G. M. (2015). Analisis Pengaruh Brand Awareness, Brand Association, Perceived Quality dan Brand Loyality Terhadap Purchase Intention Laptop Acer di Ponorogo. Skripsi, Universitas Negeri Yogyakarta.

Taufiq, S. (2014). ANALISIS PENGARUH KUALITAS PRODUK DAN BRAND AWARENESS TERHADAP KEPUTUSAN PEMBELIAN PRODUK ( Studi Kasus Pada Konsumen Produk Batik Merek The Bluesville ). Analisis Pengaruh Kualitas Produk Dan Brand Awareness Terhadap Keputusan Pembelian Produk Batik Natural Indigo Dyed, 6(3), 12. 
AKSARA: Jurnal Ilmu Pendidikan Nonformal

P-ISSN 2407-8018 E-ISSN 2721-7310 DOI prefix 10.37905

Volume 08, (1), January 2022

http://ejurnal.pps.ung.ac.id/index.php/Aksara

412 AKSARA: Jurnal Ilmu Pendidikan Nonformal 